\title{
EDITORIAL
}

\section{La Agricultura y la Ciencia}

\author{
Agriculture and Science
}

Dr. Carlos Leiva Sajuria

Vicerrector Académico Universidad de Tarapacá Arica-Chile cleivas@uta.cl

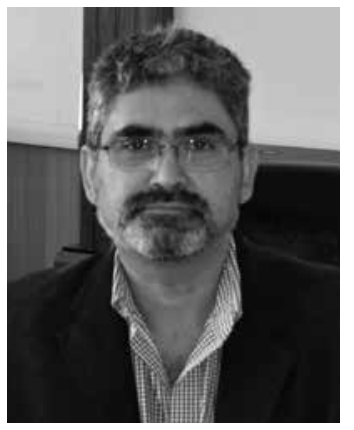

Academic Vice Rector University of Tarapacá Arica-Chile cleivas@uta.cl
La Agricultura nace en el período neolítico, generando el desarrollo de las grandes culturas de la antiguiedad. De hecho, es imposible separar el nacimiento de las civilizaciones del desarrollo de la Agricultura, la que se enriqueció a su vez de mejores técnicas creadas al seno de ellas. De este modo ha estado ocurriendo en los últimos diez mil años, en una virtuosa relación que ha permitido tener hoy una población mundial que sobrepasa cualquier cálculo que se hubiese hecho antes de nuestros tiempos modernos.

La Agricultura no solo está en la base del desarrollo de los grandes imperios de la antigüedad en el sentido político, también estuvo estrechamente ligada al desarrollo de la religiosidad. Conocido es que todos los mitos religiosos están estrechamente ligados a los ciclos de los cultivos, dando lugar a deidades famosas como Osiris y Ceres. Dio asimismo lugar a ceremonias que convocaban a toda la comunidad como son las ceremonias que se desarrollaban en los solsticios y equinoccios y que en muchos casos repetimos hoy, inconscientes de sus sentidos originales y con un sabor más comercial.

Paradójicamente fue la Agricultura la que hizo al hombre mirar al cielo y descubrir el orden que se esconde tras el caos aparente de la distribución estelar del cielo nocturno. En efecto, la astronomía debe su origen, sin duda, a la necesidad del hombre antiguo de determinar los ciclos
Agriculture began in the Neolithic period, generating the development of the great civilizations of antiquity. It is impossible to separate the birth of civilizations from the development of agriculture, which was enriched as better techniques were created by these civilizations. This has been happening for ten thousand years, in a synergic relation that has permitted the current world population to exceed all calculations made before modern times.

Agriculture is not only the base of the development of the great empires of antiquity in the political sense; it was also closely linked to the development of religion. It is well known that all religious myths are closely linked to crop cycles, giving rise to famous gods such as Osiris and Ceres. It also gave rise to ceremonies that united the entire community, such as those celebrated in solstices and equinoxes, many of which we repeat today, unconscious of the original senses and with a more commercial flavor.

Paradoxically, it was agriculture that caused people to observe the skies and discover the order hidden behind the apparent chaos of the distribution of stars in the night sky. Astronomy undoubtedly owes its origin to the need to determine the cycles that produce the optimum conditions for the 
que regían las condiciones óptimas para las distintas etapas del cultivo. Por supuesto, esto también estuvo marcado de la religiosidad que acompañaba a todas las actividades humanas de la antigüedad. De este modo Agricultura, Religión y Astronomía formaron un corpus que ha estado en el centro del desarrollo de las sociedades humanas.

Pero si la Agricultura ha estado en la base del desarrollo de la civilización, tal como ya hemos dicho, ella también se ha beneficiado de las mejores condiciones de vida que esa civilización permitió a un nuevo tipo de individuo, que nació ya en los albores de nuestra época: el científico, o en palabras más ambiciosas, el sabio. Fueron estos hombres sabios los que se dieron cuenta que podían mejorar los medios de producción mediante la introducción de nuevas tecnologías. La utilización del arado pesado permitió el cultivo más profundo de los suelos, la rotación de los cultivos el mejor aprovechamiento de suelos fértiles, se introdujo también la mejora de sistemas de regadíos, el uso de terrazas para aprovechar el cultivo de laderas. Por otro lado, la organización del suelo llevó a diferentes asociaciones agrícolas que permitieron el desarrollo del comercio a gran escala. Sin duda la Agricultura estuvo en la base del desarrollo de la edad media, época que no fue tan obscura como se nos ha hecho creer.

Durante la edad moderna también fue la Agricultura el centro de la actividad comercial entre el nuevo y el viejo mundo, la que se vio marcada por la expansión e intercambio de los cultivos. Fue en esta época que la ciencia comenzó nuevamente a marcar una nueva revolución en la Agricultura con la introducción de la mecanización, el uso de abonos químicos y estudios científicos como la edafología. En esta época se marca la diferencia entre los países desarrollados y subdesarrollados. Los primeros invirtieron grandes esfuerzos en tener un desarrollo científico y tecnológico aplicado a una Agricultura de grandes rendimientos, asociados a mercados dinámicos y libres, mientras que los segundos dejaron de lado el desarrollo científico y mantuvieron mercados rígidos asociados a políticas de fuerte control central, gobernados por las monarquías que finalmente vieron caer sus imperios.

Finalmente podemos observar el desarrollo de la Agricultura hoy, capaz de alimentar a los siete mil millones de habitantes que sobrepoblamos nuestro afligido planeta. Con suelos y recursos hídricos cada vez más escasos, solo el gran desarrollo de las ciencias como la biología y la química, con el aporte de la ingeniería así como de todas sus aplicaciones, permite y permitirá mantener el desarrollo de la different stages of crops. Of course this was also affected by religion, which accompanied all human activities in antiquity. Thus agriculture, religion and astronomy form a corpus that has been at the center of development of human societies.

As well as being at the base of the development of civilization, agriculture has also benefited from the better living conditions that allowed civilizations to develop a new kind of individual, born at the dawn of our times-the scientist, or in more ambitions terms, the wise man. It was these wise men who realized that agricultural production could be improved by introducing new technology. The introduction of the heavy plow allowed cultivation of deeper soils, crop rotation and better utilization of fertile soils; irrigation systems were also improved and terraces were used to allow cultivation on slopes. The organization of the soil led to different agricultural associations that allowed the development of large-scale commerce. Agriculture was undoubtedly at the base of the development of the Dark Ages, which were not as dark as some would have us believe.

At the beginning of the modern era agriculture was the center of commercial activity between the old and new worlds, which was marked by expansion and interchange of crops. At this time science began to produce a new revolution in agriculture with the introduction of mechanization, the use of chemical fertilizer and scientific studies such as edaphology. This period produced the difference between developed and undeveloped countries. Developed countries made undertook considerable effort to produce scientific and technological development applied to high-yield agriculture, associated with dynamic and free markets, while undeveloped countries ignored scientific development and maintained rigid markets associated with strong central control policies, governed by monarchs who finally saw the fall of their empires.

Finally, we note that today's agriculture is capable of feeding the seven billion persons that overpopulate our suffering planet. With soils and water resources becoming progressively scarcer, only considerable development in sciences such as biology and chemistry, with the support of engineering and all its applications, allows and may continue to allow the development of humanity, 
humanidad que aunque cada vez más tecnológica, sigue ligada a lo que la Tierra nos puede entregar. Solo hay que pensar que gracias al desarrollo científico un granjero que a principios del siglo veinte podía alimentar solo a cinco personas, hoy puede mantener a ciento treinta personas, gracias a la tecnología, los agroquímicos y las variedades actuales. El uso del suelo se ha hecho también cada vez más eficiente gracias a la manipulación genética, la mejor gestión de suelos y nutrientes.

Capítulo aparte merece la manipulación genética que está en boca de muchos hoy. La mejora de las especies cultivadas no es cosa de hoy, sino que está ligada a la historia misma de la Agricultura. Desde que el primer agricultor seleccionó los mejores granos para asegurar que la próxima siembra iba a ser de mejor calidad, hasta el científico que hoy en un laboratorio introduce cambios a nivel genético, que permiten que los cultivos sean más resistentes a enfermedades o puedan ser cultivados más intensivamente y en diferentes condiciones de suelo o de clima. Hace mucho tiempo que el manejo genético se introdujo en la Agricultura, solo ha cambiado la manera de hacerlo. El trigo que consumimos hoy es muy distinto de las primeras gavillas salvajes con que se hacía el pan de los constructores de pirámides en Egipto o zigurats en la antigua Mesopotamia.

La Agricultura y la ciencia han estado sin duda estrechamente ligadas al desarrollo de la humanidad y este vínculo es imposible de romper si lo que se quiere es un futuro de mayor desarrollo y equidad. which although more and more technological is always linked to what the Earth can provide. It is enough to note that thanks to scientific development, a farmer who at the beginning of the $20^{\text {th }}$ century could only feed five people today can feed 130 people, thanks to technology, agrochemicals and current plant varieties. Soil use has also become more and more efficient thanks to genetic manipulation and better management of soils and nutrients.

Genetic manipulation, about which many are talking now, merits a separate chapter. Improvement of cultivated species is not new; it is linked to the history of agriculture. It stretches from the first farmer who selected the best grains to assure that next year's crop would be of better quality to today's scientist who introduces genetic changes in a laboratory that allow crops to be more resistant to diseases or be cultivated more intensely and in different soil and climate conditions. Genetic management has been used for a long time in agriculture, only the way it is done has changed. The wheat we eat today is very different than the first wild sheaves that were used to make bread by the builders of the pyramids in Egypt and the ziggurats in ancient Mesopotamia.

Agriculture and science have certainly been linked to the development of humanity, and this link must not be broken if we want a future with more development and equality. 